\title{
Conversion of nitrogen compounds into nitrogen oxides during combustion in a fluidised bed reactor
}

\author{
B. Kowarska \& W. Żukowski \\ Department of Chemical Engineering and Technology, \\ Cracow University of Technology, Poland
}

\begin{abstract}
Combustion processes of alternative fuels with high nitrogen content can cause nitrogen oxides emission which is unacceptable from an environmental and legal point of view. Reactions of nitrogen compounds, e.g. ammonia or heterocyclic compounds, are complex and there is a lack of specialized complete knowledge about them. This paper reports processes of propane combustion in a fluidized bed reactor without and with ammonia or pyridine addition into the reaction zone, especially nitrogen compound conversion into $\mathrm{N}_{\mathrm{x}} \mathrm{O}_{\mathrm{y}}$. Ammonia is converted into $\mathrm{N}_{\mathrm{x}} \mathrm{O}_{\mathrm{y}}$ up to $78 \%$, and pyridine up to $93 \%$. The main product of their reactions is $\mathrm{NO}$ (average $97 \%$ ). Residual $\mathrm{C}_{5} \mathrm{H}_{5} \mathrm{~N}$ or $\mathrm{NH}_{3}$ are converted to $\mathrm{N}_{2}$. Nitrogen compounds' influence on processes involving $\mathrm{CO}$ and VOC. The effect of pyridine addition to the reaction zone on the kinetics of combustion process is practically negligible. The effect of ammonia addition is noticeable but limited.

Keywords: nitrogen oxides, fluidized bed combustion, alternative fuels combustion, biomass combustion.
\end{abstract}

\section{Introduction}

The principal method of obtaining energy in the entire world is the incineration of conventional fuels. Energy demand is increasing, therefore, the combustion processes must be carried out in the most effective way from an environmental and economical point of view. Combustion technologies and flue gases treatment should be appropriately chosen to obtain the exhaust fumes, which are not harmful for the environment, as a result. Replacing conventional fuels with 
alternative ones, such as biomass or municipal waste is also significant matter. Chemical energy bounded in these materials can be converted into useful form of thermal energy. Combustion of above-mentioned materials, however, entails various types of complications. One of them, that is the subject of the research presented in this publication, is the emission of nitrogen oxides which can reach up to $2500 \mathrm{mg} / \mathrm{m}^{3}$ [1] during combustion of fuels containing fuel-nitrogen. Nitrogen is present in those materials in the form of ammonia derivatives, heterocyclic compounds, etc. Nitric oxide can be produced in the combustion process, from atmospheric nitrogen, by the thermal [2] and the prompt [3-6] mechanisms. It can be also created from fuel-nitrogen, which is a process that requires less energy in comparison with thermal or prompt mechanisms. During combustion processes, nitrogen is present transiently in the radicals $\mathrm{HCN}, \mathrm{CN}$, $\mathrm{HNO}$, and $\mathrm{NH}_{\mathrm{i}}$. Their transformations lead to $\mathrm{NO}$ creation $[7,8]$. Reactions of oxidation involving nitrogen compounds are complex homogeneous, heterogeneous or catalytic processes. Nitrous and nitrogen oxides are formed mainly due to the oxidation or reduction of nitric oxide, present in the reaction zone $[9,10]$. Maintenance of the temperature in the freeboard zone above $900^{\circ} \mathrm{C}$, during combustion in a fluidised bed reactor, causes that the quantity of $\mathrm{N}_{2} \mathrm{O}$ and $\mathrm{NO}_{2}$ is only few percent of total nitrogen oxides [11-13].

Research on fuel-nitrogen transformations in the combustion processes are carried on all over the world. Part of them is focused on the processes associated with the coal combustion, as it is widely used fuel and fairly well known as a combustible material [14-18]. These experimental works include both homogeneous transformations of nitrogen compounds [14] as well as the processes of their formation depending on the composition of coal and fly ash present in the freeboard zone [15-19]. Particular attention is given to the presence of $\mathrm{CaO}$ in the reaction zone [15-21], which is due to the fact that calcium oxide is widely used for exhaust gases purifying from $\mathrm{SO}_{2}$.

No matter how complex the conversions of fuel-nitrogen compounds are, ammonia and HCN (the product of conversion of pyridine during combustion) are one of the main intermediate products of these reactions. They are products of decomposition of the fuel in the initial phase of the process and their further transformations lead to the formation of nitrogen oxides. Those processes can be written by the chemical reaction equations $[7,8,14,22]$ :

$$
\begin{gathered}
\mathrm{NH}_{3}+\mathrm{OH}=\mathrm{NH}_{2}+\mathrm{H}_{2} \mathrm{O} \\
\mathrm{NH}_{2}+\mathrm{O}=\mathrm{HNO}+\mathrm{H} \\
\mathrm{HNO}+\mathrm{H}=\mathrm{NO}+\mathrm{H}_{2} \\
\mathrm{HNO}+\mathrm{OH}=\mathrm{NO}+\mathrm{H}_{2} \mathrm{O} \\
\mathrm{HNO}+\mathrm{O}=\mathrm{NO}+\mathrm{OH} \\
\mathrm{NH}+\mathrm{O}=\mathrm{NO}+\mathrm{H} \\
\mathrm{NH}+\mathrm{OH}=\mathrm{HNO}+\mathrm{H} \\
\mathrm{HCN}+\mathrm{O}_{2}=\mathrm{NCO}+\mathrm{OH} \\
\mathrm{NCO}+\mathrm{OH}=\mathrm{NO}+\mathrm{CO} \\
\mathrm{NCO}+\mathrm{H}=\mathrm{NH}+\mathrm{CO}
\end{gathered}
$$

Formation of nitrogen oxides via this mechanism was confirmed in later studies by other researchers [14]. 
Due to the complex composition and structure of alternative fuels, and the specific hydrodynamic and temperature conditions occurring in a fluidised bed reactor a detailed course of these processes is not fully known. There is worldwide research, which has the goal of determining transformation pathways of the fuel nitrogen into nitrogen oxides [22-24]. The study presented in this paper draws this issue out. Because of intricately of combustion process of solid alternative fuels with high nitrogen content, in the first phase of this research combustion of gas - propane with the addition of controlled amounts of ammonia or pyridine was performed. Both reagents were dosed into the reaction zone in such amounts, which can be present during combustion of fuel with high nitrogen content. Results and conclusions from experiments should ensure such possibilities of design and control of combustion, which results in possibly lowest quantity of nitrogen oxides from combustion.

\section{Experimental part}

\subsection{Equipment}

Tests were performed in the laboratory scale fluidised bed reactor, which works under atmospheric pressure (Fig. 1). The reactor consists of a quartz tube with external diameter of $98 \mathrm{~mm}$, a wall thickness of $2 \mathrm{~mm}$ and a height of $500 \mathrm{~mm}$. Quartz tube is situated on gas distributor which is made of perforated steel plate with a thickness of $1 \mathrm{~mm}$, in which holes with a diameter of $0,6 \mathrm{~mm}$ are equally spaced. The reactor is equipped with a system for supplying fuel and gas mixtures as well as exhaust fumes removal. To carry on this combustion processes, the reactor was modified in relation to its previous configuration [2529]. It was added a system of $\mathrm{NH}_{3}$ and $\mathrm{C}_{5} \mathrm{H}_{5} \mathrm{~N}$ supply. To ensure a uniform distribution of ammonia in gases entering to the reaction zone, that component was dosed from gas cylinder via a flow meter to the tube where $\mathrm{NH}_{3}$ and nitrogen mixing took place. Pyridine was introduced through the dispensing system to the air distribution system to the reactor.

For all experiments, the material of the fluidised bed was chemically inert sand with particles size $0.385-0.430 \mathrm{~mm}$, a weight of about $400 \mathrm{~g}$ and $38 \mathrm{~mm}$ of static height.

The fluidised bed has a temperature control system in the reaction zone (in the bed), consisting of a movable radiation shield and blower of a cold air.

\subsection{Analytical and measurement methods}

The temperature in the fluidized bed was measured by a set of eight thermocouples mounted in the reactor axis, at distances of 5 to $70 \mathrm{~mm}$ above the distributor. Dynamic phenomena occurred during combustion were analyzed on the basis of the registered changes of dynamic pressure. Registration was carried out using a difference sensor mounted in the chamber, under gas distributor and by the microphone, which was located about $150 \mathrm{~mm}$ above the reactor. Measurement and recording of exhaust gases from combustion zone composition 


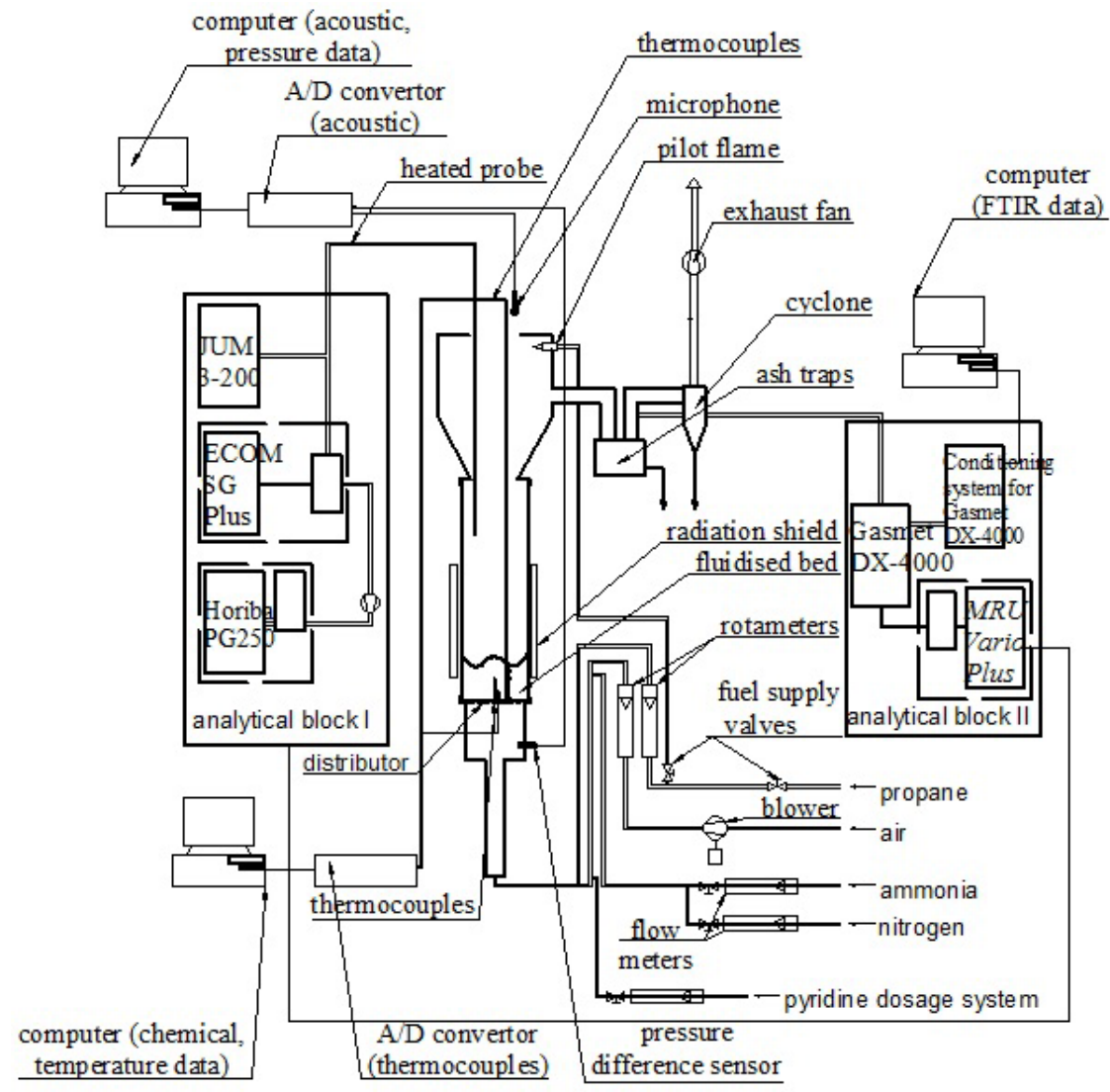

Figure 1: Schematic representation of fluidised bed reactor.

was performed using analytical equipment: total organic compounds analyzer (JUM Model 3-200); $\mathrm{O}_{2}, \mathrm{CO}, \mathrm{NO}, \mathrm{NO}_{2}, \mathrm{SO}_{2}$ analyzer (ECOM SG Plus); $\mathrm{O}_{2}, \mathrm{CO}$, $\mathrm{CO}_{2}, \mathrm{SO}_{2} \quad \mathrm{NO}_{\mathrm{x}}, \mathrm{N}_{2} \mathrm{O}$ analyzer (Horiba PG250); FTIR analyzer (Gasmet DX4000); $\mathrm{O}_{2}, \mathrm{CO}, \mathrm{NO}, \mathrm{NO}_{2}, \mathrm{SO}_{2}, \mathrm{CH}_{4}, \mathrm{CO}_{2}$ analyzer (MRU Vario Plus) (Fig. 1). Analysers were divided into two analytical blocks. To the first one, flue gases were collected by heated probe (whose outlet was placed approximately $400 \mathrm{~mm}$ above the gas distributor), were guided (collection point I). Part of the exhaust fumes, which required prior dilution was directed into analytical block II. After passing through the first measuring cross-section flue gases were rapidly cooled and mixed with secondary air in a ratio of about 1:3. From partially dedusted, in ash trap for crosier particles, exhaust fumes sample was taken (collection point II), which was then directed to the analysers.

\subsection{Procedure}

Propane combustion in fluidised bed reactor were carried out, with and without addition of $\mathrm{N}$-containing components (Fig. 1). In part of them to the air-propane 
mixture gaseous ammonia or liquid pyridine were added. Effects of their transformation under application of their different quantities to the reaction zone, during the combustion process in a fluidised bed were studied. Experiment were initiated with fluidisation of bed at ambient temperature by air with rate of flow $1.66 \mathrm{dm}^{3} / \mathrm{s}$. Next step was starting dosage of ammonia with nitrogen or pyridine to the reactor. Rate of flow of nitrogen compounds was maintained constant during the experiment, whereas in subsequent experiments different amounts of $\mathrm{NH}_{3}$ or $\mathrm{C}_{5} \mathrm{H}_{5} \mathrm{~N}$ were used. During the experiments with ammonia, in a first trial, about $280 \mathrm{ml} / \mathrm{min}$ of ammonia with the addition of $7.74 \mathrm{l} / \mathrm{min}$ of nitrogen was dosed to the reactor, in a second one $\sim 500 \mathrm{ml} / \mathrm{min}$ of ammonia with $7.74 / \mathrm{min}$ $\mathrm{N}_{2}$. When experiments with the addition of pyridine were run, in the first experiment about $13 \mathrm{ml} / \mathrm{h}$ of $\mathrm{C}_{5} \mathrm{H}_{5} \mathrm{~N}$ was dosed, in the second experiment $\sim 54 \mathrm{ml} / \mathrm{h}$. In the next stage, propane dosing was started into the reactor (rate of flow $\sim 0,043 \mathrm{dm}^{3} / \mathrm{s}$ ), which resulted in the creation of such fuel-air mixture composition that the air-fuel ratio value $\lambda_{\text {bed }}$ was about 1.4 . With the start of the propane addition, ignition was initiated. The process was carried out in a manner to obtain a gradual increase in bed temperature from ambient temperature to $950-1000^{\circ} \mathrm{C}$, then cooling of the reactor with a stream of outside to lower the temperature of the bed was run.

\section{Results and discussion}

Changes in temperature, bed height, the concentrations of chosen compounds in the flue gases during combustion of propane with ammonia $(500 \mathrm{ml} / \mathrm{min})$ or pyridine $(54 \mathrm{ml} / \mathrm{h})$, are shown in Figure 2 . After ignition of fuel-air mixture, combustion in both cases proceeded over a fluidised bed, which height was about $50 \mathrm{~mm}$ under the bed temperature $\sim 600^{\circ} \mathrm{C}$ (Fig. 2b), g)). In the initial period of combustion, the rise of temperature recorded by the thermocouples located above the surface of the bed, which were in contact with the flame, was observed. Thermocouples inside the bed heated up much slower, with a gradual increase of bed particles temperature (Fig. 2a), f)). The effect of increasing the average temperature of the bed was increasing of the volume of gas flowing through the bed, and thus increasing of the bed dynamic height (Fig. 2b), g)). From the moment that all thermocouples were immersed in the bed, temperature measured by them was similar (Fig. 2a), f)). The combustion of gaseous fuel with air in a fluidised bed, leads to changes of the maximum temperature location measured in the bed, depending on its average temperature. With increase of average temperature, the maximum was moving from the bed surface towards the distributor. This shows that it was the direction where zone of the most intense exothermic reaction was being relocated (Fig. 2a), b) and f), g)). In a bed, where an average temperature was above $940^{\circ} \mathrm{C}$, chemical combustion processes took place mainly in the area of $5 \mathrm{~mm}$ above the distributor nevertheless bed high is then about $100 \mathrm{~mm}$. 

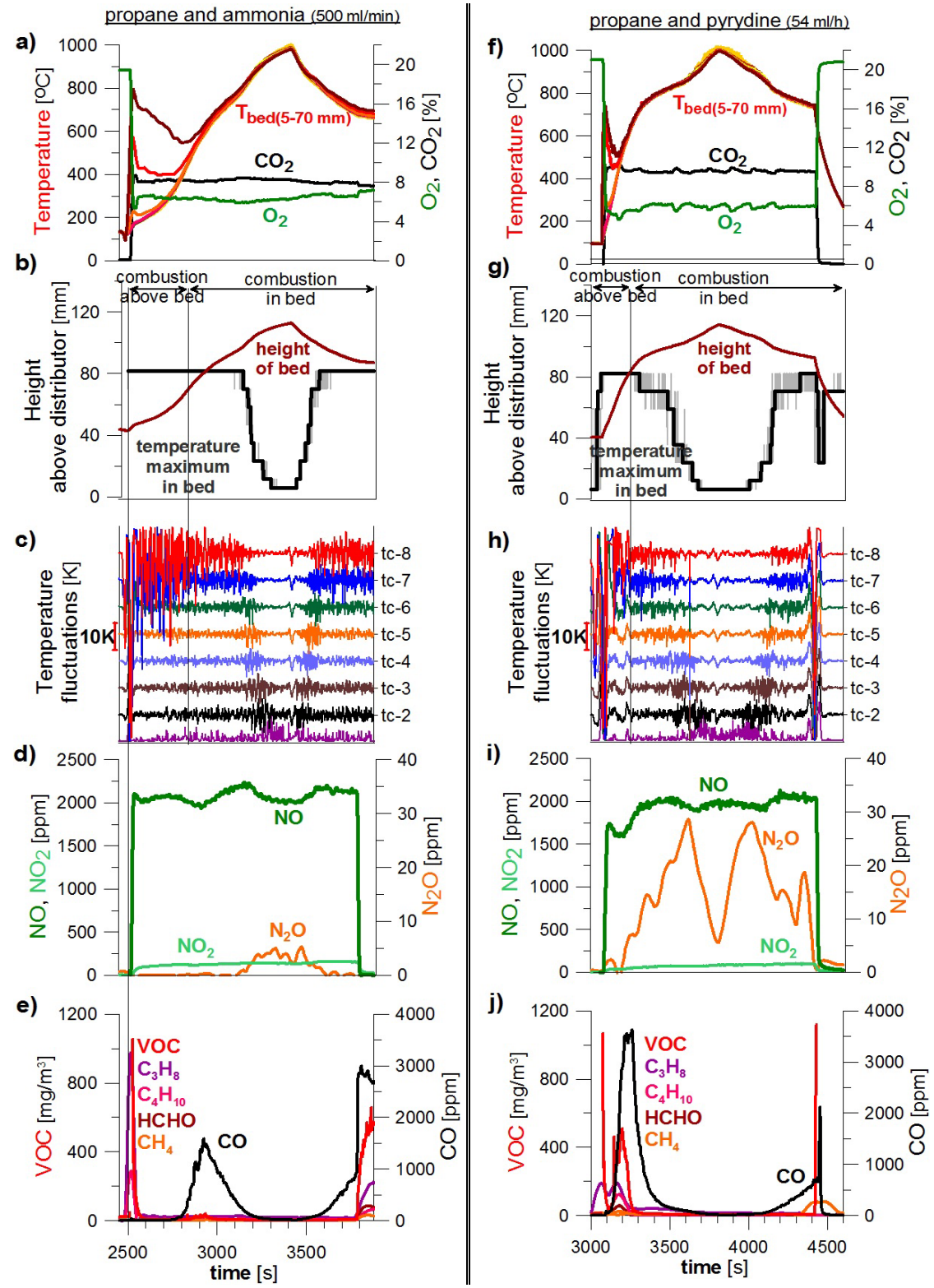

Figure 2: Process of propane combustion with addition of ammonia $(500 \mathrm{ml} / \mathrm{min})$ a-e or pyridine $(54 \mathrm{ml} / \mathrm{h}) \mathrm{f}-\mathrm{j}:$ a) temperature and oxygen and carbon dioxide concentrations in flue gases; b) changes in the bed height and the maximum temperature location; c) temperature fluctuations; d) nitrogen oxides concentration in flue gases; e) concentrations of chosen gaseous compounds, containing carbon in their structure in flue gases. 
Analysis of temperature fluctuations provides additional information about the location of the zone where combustion took place. In this zone the highest values of temperature fluctuations were recorded, what was the result of the discontinuity of the combustion processes in the bed. Combustion runs there mainly in bubbles and has explosive nature. The effects of this kind of processes were short-term increases of both the temperature and the pressure. As shown in Figures 2c) and h) max temperature fluctuations moved towards the distributor during the process with an increase in average temperature in the bed and accurately reflects changes in the position of the zone of the highest temperature (Fig. 2b), g)).

Analysis of the conversion process of ammonia to nitrogen oxides shows that with the start of combustion in a fluidised bed reactor, an increase in the concentration of $\mathrm{NO}_{\mathrm{x}}$ in the exhaust fumes was recorded. The amount of nitric oxide reached a value of approximately $2090 \mathrm{ppm}$. The concentration of nitrogen oxide was, however, significantly lower - about $120 \mathrm{ppm}$. The concentration of nitrous oxide does not exceed a value of $10 \mathrm{ppm}$ (Figure $2 \mathrm{~d}$ )). In case when pyridine was added to propane, concentration of nitric oxide in the exhaust fumes was near $2020 \mathrm{ppm}$, nitrogen oxide about $100 \mathrm{ppm}$, and concentration of nitrous oxide was lower than $30 \mathrm{ppm}$ (Fig. 2i)). The recorded results demonstrate that both the ammonia and pyridine are predominantly converted into nitric oxide (Fig. 2d), i)).

Emission of carbon monoxide in the combustion processes depends on the temperature in the reaction zone and the conditions of oxidation reactions to carbon dioxide. During combustion above the bed, in a flame, the concentration of $\mathrm{CO}$ oscillated within value of $10 \mathrm{ppm}$ in case of propane combustion with ammonia (Figure 2e)). When pyridine was added to the fuel, low concentration of $\mathrm{CO}$ was recorded at bed temperature below $200^{\circ} \mathrm{C}$ (Fig. 2j)). When the reaction zone relocated from above the bed into the bed, and the average temperature was lower than $\sim 600^{\circ} \mathrm{C}$, however rapid increase in the concentration of carbon monoxide in both cases was observed. Maximum concentration of $\mathrm{CO}$ was smaller when ammonia was used as a fuel additive. However, achieving a temperature above $950^{\circ} \mathrm{C}$ resulted in the emission of $\mathrm{CO}$ lower than $20 \mathrm{ppm}$, in both these cases (Fig. 2e), j)).

The concentration of volatile organic compounds in the exhaust fumes is not higher than $40 \mathrm{mg} / \mathrm{m}^{3}$, during period when the bed temperature exceeded $700^{\circ} \mathrm{C}$ (Fig. 2e), j)).

Changes of temperature profiles, temperature fluctuations and the location of combustion process in a fluidised bed and associated with that changes of the chemical transformations mechanisms, for the combustion of propane without or with the addition of different amounts of ammonia or pyridine, are similar to those discussed above. Changes of selected components concentration in flue gases are different and depend on whether ammonia or pyridine were or were not dosed to the reactor. Analysis of combustion process organization in time and in particular the composition of the exhaust fumes indicates that these changes are dependent on the temperature, therefore detailed analysis of those parameters as a function of the average bed temperature (mean arithmetic of 4 . temperature 
a)

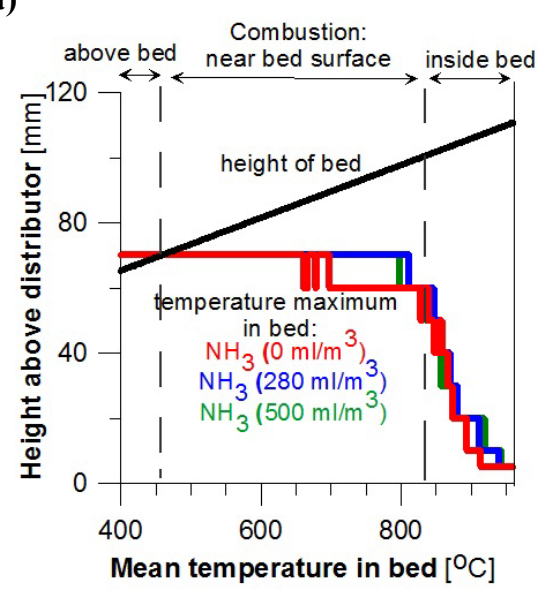

b)

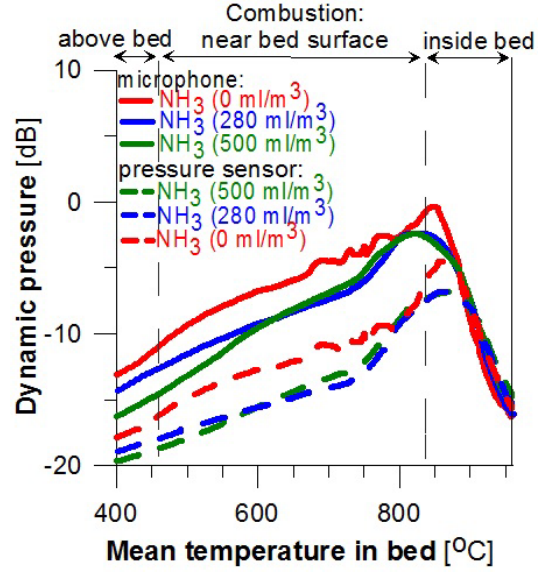

(f)

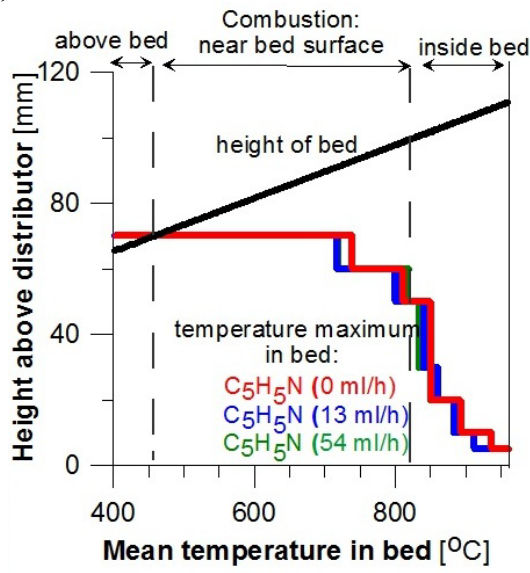

g)

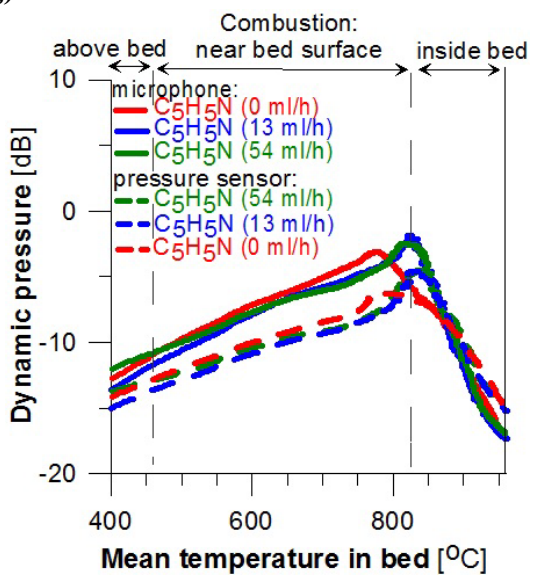

Figure 3: Changes of chosen parameters of propane combustion processes with and without addition of $\mathrm{NH}_{3}$ or $\mathrm{C}_{5} \mathrm{H}_{5} \mathrm{~N}$ and concentrations of chosen compounds in flue gases as a function of mean bed temperature: a), f) height of the fluidized bed and the maximum temperature location during process; b), g) dynamic pressure registered by microphone and pressure difference sensor; c), h) nitrogen oxides concentration; d), i) carbon monoxide concentration; e), j) volatile organic compounds concentration. 
c)

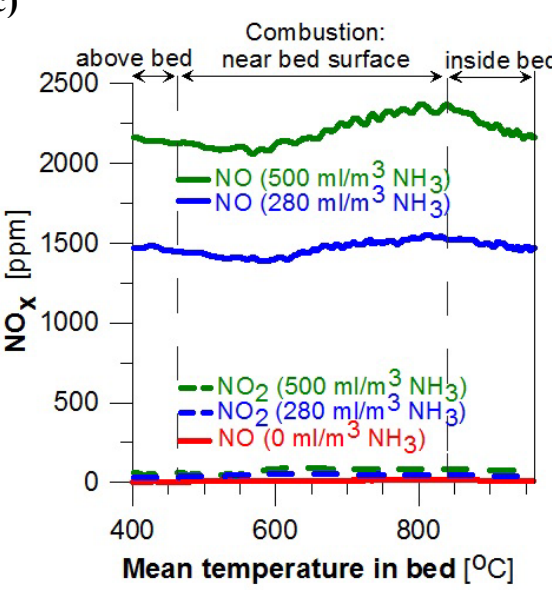

d)

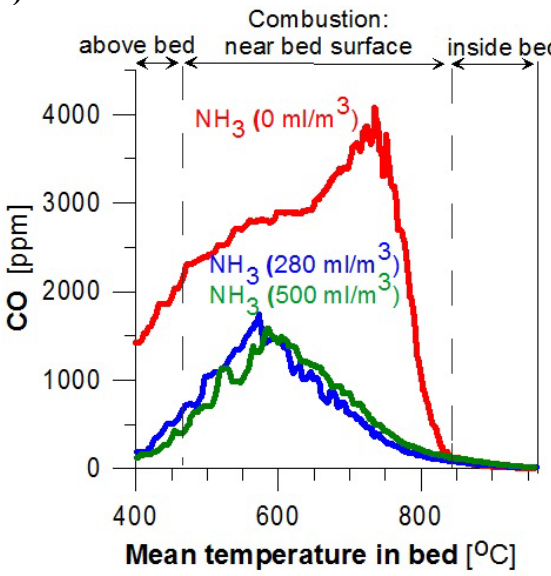

e)

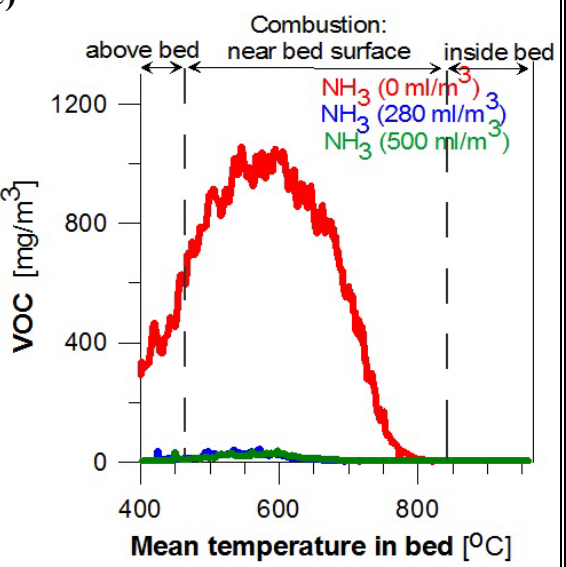

Figure 3: h)

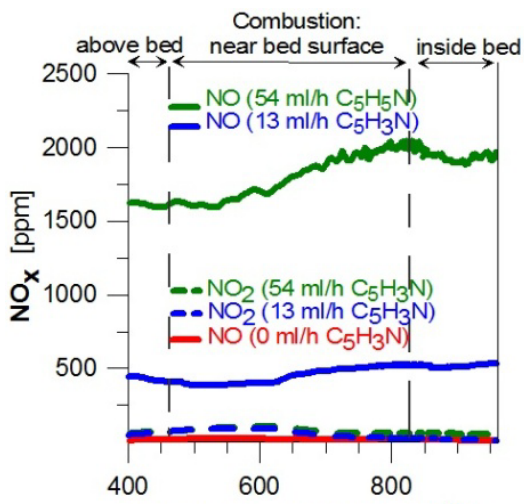

Mean temperature in bed $\left[{ }^{\circ} \mathrm{C}\right]$

i)

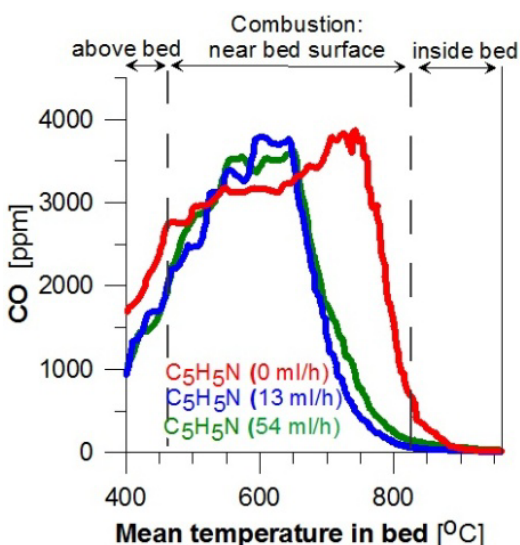

j)

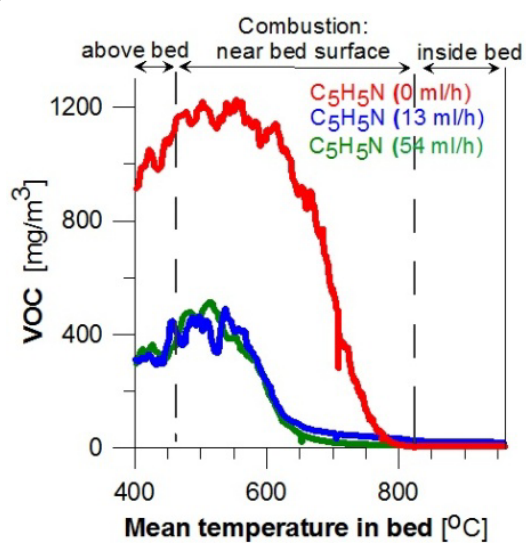

Continued. 
measured by the thermocouple located 10 to $30 \mathrm{~mm}$ above the distributor) was carried out (Fig. 3a)-j)). Changing of combustion zone location in the reactor and the height of the surface of the bed as a function of temperature for all tests are compiled in Figure 3a), f). The step-lines represent the position of temperature maximum in the vertical profile of the reactor. During all experiments, the displacement of the combustion process from the area above the fluidized bed on the bed surface took place at low temperature $\left(\sim 460^{\circ} \mathrm{C}\right)$. Further increasing the temperature causes progressive bed expansion and what is related to that, combustion process run in the fluidized bed. However, combustion occurred invariably at the same height above the distributor. Starting from a temperature of $\sim 840^{\circ} \mathrm{C}$, it can be seen a significant movement of the reaction zone deep into a bed, to gas distributor under the bed temperature $920-940^{\circ} \mathrm{C}$. Over the temperature $840^{\circ} \mathrm{C}$ autoignition in bubbles occurred during the shorter time that was necessary to pass their way through the bed (Fig. 3a), f)).

Analysis of acoustic phenomena recorded during combustion, provided information about changes of the process dynamics. For instance, with the temperature increasing, the change of the process dynamics occurred and related to that characteristic sound effects were observed [30-32]. When the temperature in the combustion zone was relatively low, signal amplitude in all analyzed experiments was low, in both cases recorded by a microphone and by a difference pressure sensor. That is caused by continuous manner of the combustion in flame (Fig. 3b), g)). The temperature increase at the initiation of combustion on the bed surface causes the change of the combustion mechanism into periodic, explosive combustion in large bubbles. Hence the recorded dynamics of sound pressure increased as single peaks with fairly larger amplitude. Observed intensity of the pulses strength is higher in signals recorded by microphone than by difference sensor placed under the bed. In the temperature range $800-840^{\circ} \mathrm{C}$ dynamics of acoustic signals reached the maximum level. Further increasing of temperature resulted in the movement of process deep into the bed. Bubbles with gases exploding inside them became less noisy and the energy released during the explosions was less. It causes reduction of the acoustic signal amplitude. Acoustic pressure wave is additionally suppressed by high bed layer located over the area of the most intense run of combustion reactions. It is also characteristic that, for a given temperature of the combustion region, inside the bed, greater amplitude was recorded by the difference sensor. This is a result of the combustion occurrence near the distributor, so closer to the sensor and at a considerable distance from the microphone (Fig. 3b), g)).

Changes in the dynamic pressure recorded by a microphone are similar in all experiments (Fig. 3b), g)). Similarly, in the case of changes registered by the difference sensor. This indicates that the kinetics of propane combustion without and with the addition of ammonia or pyridine is very similar. However, in the case of propane combustion with $\mathrm{NH}_{3}$, a characteristic difference can be observed. When the combustion process run above the bed or near its surface i.e. when the bed temperature was less than $840^{\circ} \mathrm{C}$ (Fig. 3b), measured dynamic pressure was lower than one recorded when propane was burned without the 
addition of ammonia. This difference was not observed when the bed temperature exceeded $840^{\circ} \mathrm{C}$. This effect can be caused by the influence of ammonia on reduction of combustion reactions velocity in large bubbles, near the surface of the bed and in the freeboard zone. Explosive combustion is then less violent, and the amplitude of acoustic vibrations reduced. The magnitude of this impact cannot be too high, because difference of the dynamic pressures measured when combustion took place within the bed disappeared. When mixture containing pyridine was combusted, measured dynamic pressure at a temperature lower than $840^{\circ} \mathrm{C}$ was very similar to the one recorded when only propane was combusted (Fig. 3g)).

When ammonia or pyridine were not dosed into the reaction zone, concentration of nitrogen oxides $\left(\mathrm{NO}_{\mathrm{x}}\right)$ in the exhaust fumes did not exceed $20 \mathrm{ppm}$ (Fig. 3c), h)). Under conditions of fluidised bed combustion, they were mainly formed by the prompt mechanism involving hydrocarbon radicals present in the system [9]. With the initiation of ammonia or pyridine dosing to the reactor, concentration of $\mathrm{NO}$ and $\mathrm{NO}_{2}$ in the exhaust fumes increased significantly (Fig. 3c), h)). This is a consequence of oxidation of these compounds, a process, which leads mainly to the formation of nitrogen oxides. The efficiency of ammonia to $\mathrm{NO}_{\mathrm{x}}$ conversion process decreases with the increasing amount of $\mathrm{NH}_{3}$ present in the system. When the rate of flow of $\mathrm{NH}_{3}$ added to the reactor was $280 \mathrm{ml} / \mathrm{min}$, the maximum degree of conversion to $\mathrm{NO}_{\mathrm{x}}$ during combustion was $78 \%$. When the dosage of $\mathrm{NH}_{3}$ was changed into 500 $\mathrm{ml} / \mathrm{min}$, the maximum conversion decreased to $68 \%$. When pyridine was added to propane, the maximum degree of its conversion to $\mathrm{N}_{\mathrm{x}} \mathrm{O}_{\mathrm{y}}$ reached $93 \%$ (dosage of pyridine: $13 \mathrm{ml} / \mathrm{h}$ ). When larger quantities of that compound were introduced into the reaction zone, its conversion declined to $83 \%$. The main product of these reactions was nitric oxide, which constituted about $97 \%$ of the total created $\mathrm{NO}_{\mathrm{x}}$, in all experiments with the addition of ammonia or pyridine. Nitrous oxide was formed in an amount not exceeding $5 \mathrm{ppm}$, when $\mathrm{NH}_{3}$ was added to the fluidised bed and less than $30 \mathrm{ppm}$ during dosage of pyridine. Since ammonia, pyridine or other nitrogen-containing organic compounds were not register in the flue gases, it was considered that the only product beside nitrogen oxides was $\mathrm{N}_{2}$. The dependence of $\mathrm{NO}$ from $\mathrm{NH}_{3}$ formation efficiency, as a function of temperature revealed that with the movement of the combustion zone from above the bed into the vicinity of the bed surface and slow entering into the bed (temperature of about $460^{\circ} \mathrm{C}$ ), a slight decrease in the amount of synthesized nitrogen oxides was observed (Fig. 3c). The temperature increase above $600^{\circ} \mathrm{C}$ caused an increase in the efficiency of NO formation no matter if pyridine or ammonia were present in the combustion zone and the maximum concentration was measured when the bed temperature was about $800^{\circ} \mathrm{C}$ (Fig. 3c), h)). A further increase of bed temperature caused $\sim 10 \%$ reduction of $\mathrm{NO}_{\mathrm{x}}$ emissions (Fig. $3 \mathrm{c}$ ), h)), which was related to the movement of the combustion zone into the bed (where combustion inside bubbles is the dominant mechanism). Changes of $\mathrm{NO}_{2}$ concentration in exhaust fumes occurred in the similar way. Similar changes of $\mathrm{NO}_{\mathrm{x}}$ concentration with temperature, regardless of whether pyridine or ammonia were present in reactor or what concentration they had in reaction zone, allow to 
formulate a conclusion that the reactions leading to the formation of nitrogen $\mathrm{NO}_{\mathrm{x}}$ from fuel nitrogen, $\mathrm{NH}_{3}$ or pyridine occur under similar kinetics as those present in prompt mechanism.

Changes in the concentration of other components of the flue gases depending on the temperature in the reaction zone, are also characteristic (Fig. 3d), e), i), j)). During the experiment when no ammonia or pyridine was dosed to the reactor, the amount of $\mathrm{CO}$ in the exhaust fumes increased sharply with temperature increasing, to the maximum value $\sim 4050 \mathrm{ppm}$ at about $730^{\circ} \mathrm{C}$ (Fig. $3 \mathrm{~d}$ ), i)). This increase was due to the inhibitory effect of not hot bed for the oxidation process of $\mathrm{CO}$ to $\mathrm{CO}_{2}$. Further increase of temperature caused a rapid decrease of $\mathrm{CO}$ concentration in the exhaust fumes, so that for bed temperature above $900^{\circ} \mathrm{C}$ concentration of carbon monoxide was at the level of several ppm. Addition of ammonia to combustible mixture caused a significant reduction of $\mathrm{CO}$ concentration in the temperature range at which combustion ran above or near the surface of the bed. When the process was performed above temperature of $400^{\circ} \mathrm{C}$ the amount of $\mathrm{CO}$ increased, reaching maximum level respectively $\sim 1717 \mathrm{ppm}$ when $280 \mathrm{ml} / \mathrm{min}$ of $\mathrm{NH}_{3}$ was dosed and $\sim 1580\left(\mathrm{NH}_{3}\right.$ dose $\sim 500 \mathrm{ml} / \mathrm{min}$ ) for temperature $\sim 580^{\circ} \mathrm{C}$. This temperature is about $150^{\circ} \mathrm{C}$ lower than in the case described above. Increase in the bed temperature above this value caused a decrease in the concentration of $\mathrm{CO}$ in the exhaust fumes. Also in these cases for the bed temperature greater than $900^{\circ} \mathrm{C}$, carbon monoxide was at a level of several ppm (Fig. 3d)). Changes in $\mathrm{CO}$ concentration took place in a different manner when pyridine was added to the reaction zone. At a temperature $\sim 600^{\circ} \mathrm{C}$ the concentration of $\mathrm{CO}$ in the flue gases was about $8 \%$ higher than for the same temperature when no $\mathrm{C}_{5} \mathrm{H}_{5} \mathrm{~N}$ was added to the propane. The maximum value of $\mathrm{CO}$ concentration was about $3800 \mathrm{ppm}$ and it was a value similar to the maximum concentration of $\mathrm{CO}$ in the experiment when only propane was combusted (maximum occurred there in temperature of about $730^{\circ} \mathrm{C}$ so $130^{\circ} \mathrm{C}$ higher) (Fig. 3i)). Further increasing of temperature in the reaction zone, when pyridine was present in reactor, leaded to a rapid reduction of $\mathrm{CO}$ amount in the exhaust fumes, as in the case of other presented experiments (Fig. 3i)).

The highest concentration of VOC in the exhaust fumes - about 1000-1200 $\mathrm{mg} / \mathrm{m}^{3}$ - was measured when propane was combusted alone and the bed temperature was about $560^{\circ} \mathrm{C}$. In experiments with the application of ammonia, the maximum VOC concentration was approximately $40 \mathrm{mg} / \mathrm{m}^{3}$. Only when the bed temperature was higher than $700^{\circ} \mathrm{C}$ VOC concentration decreased rapidly reaching in the temperature above $800^{\circ} \mathrm{C}$ level of several $\mathrm{mg} / \mathrm{m}^{3}$ (Fig. 3e)). In the case of pyridine addition to the propane, the amount of volatile organic compounds was less than in case when propane was incinerated alone, but reached the level of $500 \mathrm{mg} / \mathrm{m}^{3}$ at a temperature $\sim 560^{\circ} \mathrm{C}$. Also here, when the temperature was higher than $800^{\circ} \mathrm{C}$, VOC concentration was lower than several $\mathrm{mg} / \mathrm{m}^{3}$ (Fig. 3j)).

On the basis of the recorded phenomena, it can be surmised that nitrogen oxides and radicals, which were the intermediate products of ammonia conversion, were involved in the reactions of $\mathrm{CO}$ oxidation. Professor Hayhurst 
claims that important heterogeneous reaction, which runs in the reaction zone at the ash grains, is [16]:

$$
\mathrm{CO}+\mathrm{NO}=\mathrm{CO}_{2}+\mathrm{N}_{2}
$$

Occurrence of this reaction in conditions of presented research with ammonia application may be proper because of decrease in the concentration of NO and $\mathrm{CO}$ (in relation to the concentrations of these substances registered when propane without addition of ammonia was combusted). The conversion of NO to $\mathrm{NO}_{2}$, which was observed in the presence of $\mathrm{CO}$ in previous studies [4] has not been established because within temperature, in which decrease in concentration of $\mathrm{NO}$ and $\mathrm{CO}$ and VOC is observed, an increase in the concentration of $\mathrm{NO}_{2}$ is not noticed. However, chemical changes mentioned by equation No. 11 when pyridine is present in the reaction zone, did not occur because it was not noticed lowering of $\mathrm{NO}$ and $\mathrm{CO}$ concentrations at a temperature $\sim 560^{\circ} \mathrm{C}$.

\section{Conclusions}

During combustion of gaseous fuels in a fluidised bed reactor, ammonia present in the reaction zone is converted into $\mathrm{N}_{\mathrm{x}} \mathrm{O}_{\mathrm{y}}$ up to $78 \%$, and pyridine up to $93 \%$. The degree of conversion is smaller when greater is the amount of additives dosed into reaction zone. The main product of the conversion of nitrogen compounds is $\mathrm{NO}$ (average 97\%). Residual $\mathrm{C}_{5} \mathrm{H}_{5} \mathrm{~N}$ or $\mathrm{NH}_{3}$ are converted to $\mathrm{N}_{2}$.

Ammonia, pyridine and nitric oxide present in the reaction zone influence on reduction of the temperature by which occur changes involving $\mathrm{CO}$ or VOCs. In addition, $\mathrm{NH}_{3}$ and $\mathrm{NO}$ affect the acceleration of processes involving $\mathrm{CO}$ and VOC. The degree of their conversion is at high level at temperature $\sim 800^{\circ} \mathrm{C}$, when the combustion takes place yet near bed surface.

During combustion processes, $\mathrm{N}_{2} \mathrm{O}$ is detected in flue gases at a level not exceeding $30 \mathrm{ppm}$.

Combustion runs close to the gas distributor under the highest temperature.

Effect of pyridine addition to the reaction zone on the kinetics of combustion process is practically negligible. When ammonia is added to propane effect is noticeable but limited. It can therefore be assumed that this impact will also be limited during the combustion of alternative fuels with high fuel-nitrogen content. Ammonia and pyridine are in fact one of the major products of nitrogen compounds conversion in initial phase of combustion. Their further reactions lead to the formation of nitrogen oxides.

\section{Acknowledgement}

The presented work has been financed within the scope of the Grant no. DEC2011/03/N/ST8/06355 by the National Science Centre (Poland). 


\section{References}

[1] Petersen I., Werther J., Experimental investigation and modeling of gasification of sewage sludge in the circulating fluidized bed. Chemical Engineering and Processing: Process Intensification, 44, pp. 717-736, 2005.

[2] Zeldovich J.B., Rajzer I.P., Fizyka udarnych wotn i wysokotemperaturnych gidrodynamiczeskich jewlenij, Moscow 1963.

[3] Fenimore C.P., Formation of nitric oxide in permixed hydrocarbon flames. Symposium (International) on Combustion, 13, pp. 373-380, 1971.

[4] Baron J., Bulewicz E.M., Żukowski W., Kandefer S., Pilawska M., Combustion of Hydrocarbon Fuels in a Bubbling Fluidized Bed. Combustion and Flame, 128, pp. 410-421, 2002.

[5] Fenimore C.P., Jones G.W., Rate of the reaction $\mathrm{O}+\mathrm{N}_{2} \mathrm{O} \rightarrow 2 \mathrm{NO}$. Symposium (International) on Combustion, 8, pp. 127-133, 1991.

[6] Bachmaier F., Eberius K.H., Just T., The Formation of Nitric Oxide and the detection of $\mathrm{HCN}$ in Premixed Hydrocarbon-Air Flames at 1 Atmosphere. Combustion Science and Technology, 7, pp. 77-84, 1973.

[7] Bartok W., Sarofim A.F., Fossil fuel combustion: a source book, John Wiley \& Sons Inc: New York, 1991.

[8] Glassman I., Combustion, Third Edition, Academic Press: New York, 1996.

[9] Miller I.A., Bowman C.T., Mechanism and modeling of nitrogen chemistry in combustion. Progress in Energy and Combustion Science, 15, pp. 287-338, 1989.

[10] Konnov A.A., Dyakov I.V., Nitrous oxide conversion in laminar premixed flames of $\mathrm{CH}_{4}+\mathrm{O}_{2}+$ Ar. Proceedings of the Combustion Institute, 32, pp. 319-326, 2009.

[11] Bonn B., Pelz G., Baumann H., Formation and decomposition of $\mathrm{N}_{2} \mathrm{O}$ in fluidized bed boilers. Fuel, 74, pp. 163-171, 1995.

[12] Armesto L., Boerrigter H., Bahillo A., Otero J., $\mathrm{N}_{2} \mathrm{O}$ emission from fluidised bed combustion. The effect of fuel characteristic and operating conditions. Fuel, 82, pp. 1845-1850, 2003.

[13] Svoboda K., Baxter D., Martinec J., Nitrous oxide emission from Waste Incineration. Chemical Papers, 60, pp. 78-90, 2006.

[14] Schäfer S., Bonn B., Hydrolysis of HCN as an important step in nitrogen oxide formation in fluidised combustion. Part 1. Homogeneous reactions. Fuel, 79, pp. 1239-1246, 2000.

[15] Schäfer S., Bonn B., Hydrolysis of HCN as an important step in nitrogen oxide formation in fluidised combustion. Part II. Heterogeneous reactions involving limestone. Fuel, 81, 1641-1646, 2002.

[16] Hayhurst A. N., Lawrence A. D., The effect of solid $\mathrm{CaO}$ on the production of $\mathrm{NO}_{\mathrm{x}}$ and $\mathrm{N}_{2} \mathrm{O}$ in fluidized bed combustors: Studies using pyridine as a prototypical nitrogenous fuel. Combustion and flame, 105, pp. 511-527, 1996. 
[17] Svoboda K., Pohořelý M., Influence of operating conditions and coal properties on $\mathrm{NO}_{\mathrm{x}}$ and $\mathrm{N}_{2} \mathrm{O}$ emissions in pressurized fluidized bed combustion of subbituminous coals. Fuel, 83, pp. 1095-1103, 2004.

[18] Hou X., Zhang H., Yang S., Lu J., Yue G., $\mathrm{N}_{2} \mathrm{O}$ decomposition over the circulating ashes from coal-fired CFB boilers. Chemical Engineering Journal, 140, pp. 43-51, 2008.

[19] Wang X.B., Tan H.Z., Wang C.L., Zhao Q.X., Xu T.M., Hui S.E., Effect of metal oxide on the emission of $\mathrm{N}_{2} \mathrm{O}$ and $\mathrm{NO}$ in fluidized bed temperature range using pyridine as a nitrogenous model fuel. Proceedings of the 20th International Conference on Fluidized Bed Combustion, pp. 1017-1021, 2009.

[20] Tarelho L.A.C., Matos M.A.A., Pereira F.J.M.A., Influence of limestone addition on the behaviour of $\mathrm{NO}$ and $\mathrm{N}_{2} \mathrm{O}$ during fluidised bed coal combustion. Fuel, 85, pp. 967-977, 2006.

[21] Liu H., Gibbs B.M., The influence of calcined limestone on $\mathrm{NO}_{x}$ and $\mathrm{N}_{2} \mathrm{O}$ emission from char combustion in fluidized bed combustors. Fuel, 80, pp. 1211-1215, 2001.

[22] Mendiara T., Glarborg P., Ammonia chemistry in oxy-fuel combustion of methane. Combustion and Flame, 156, pp. 1937-1949, 2009.

[23] Li B., Li Y. H. Z., Konnov A.A., Measurements of NO concentration in $\mathrm{NH}_{3}$-doped $\mathrm{CH}_{4}+$ air flames using saturated laser-induced fluorescence and probe sampling. Combustion and Flame, 160, pp. 40-46, 2013.

[24] Glarborg P., Jensen A.D., Johnsson J.E., Fuel nitrogen conversion in solid fuel fired systems. Progress in Energy and Combustion Science, 29, pp. 89-113, 2003.

[25] Olek M., Baron J., Żukowski W., Thermal decomposition of selected chlorinated hydrocarbons during gas combustion in fluidized bed. Chemistry Central Journal, 7(1), 2013.

[26] Olek M., Baron J., Żukowski W., Mineralizacja odpadów kostnych w reaktorze fluldyzacyjnym. Przemyst Chemiczny, 92(6), pp. 991-996, 2013.

[27] Zabagło J., Baron J., Olek M., Kandefer S., Żukowski W., The use of the fluidized bed boiler for the disposal of the multi-material packaging waste. Polish Journal of Chemical Technology, 12(4), pp. 19-21, 2010. Online http://www.degruyter.com/view/j/pjct.2010.12.issue-4/v10026-010-00439/v10026-010-0043-9.xml

[28] Woynarowska A., Kandefer S., Olek M., Żelazny S., Żukowski W., Termiczna dekompozycja odpadów elektronicznych $z$ wykorzystaniem reaktora fluidyzacyjnego. Przemyst Chemiczny, 90(7), pp. 1412-1418, 2011.

[29] Żukowski W., Baron J., Kowarska B., Olek M., Zabagło J., Termiczna regeneracja ziem bielących $\mathrm{w}$ reaktorze fluidyzacyjnym. Przemyst Chemiczny, 90(5), pp. 1107-1112, 2011.

[30] Żukowski W., Acoustic effects during the combustion of gaseous fuels in a bubbling fluidized bed Combustion and Flame, 117, pp. 629-635, 1999. 
[31] Żukowski W., An acoustic method of studying sequential explosions during gas combustion in bubbling fluidized beds Combustion and Flame, 125, pp. 1075-1082, 2001.

[32] Żukowski W., The pressure pulses generated by the combustion of natural gas in bubbling fluidized beds. Combustion and Flame, 130, pp. 15-26, 2002. 